\title{
CONVERSATIONS 1: Climate Change
}

\section{Editorial Note}

Jagdish Krishnaswamy *

In 2017, too, intense rain events, especially in urban areas and the increasingly spatial and temporal variability of rainfall distribution brought into the limelight the issue of attribution of extreme weather events to climate change. In our inaugural issue we have three perspectives on climate change from a diverse set of authors: Bob Watson, Thomas Sterner, and Nitin Desai. Three points emerge from their conversations.

The first is that anthropogenic climate change is already transforming climate and that these changes will continue-regionally and globally.

Secondly, even if countries do not take on agreed commitments to cut emissions, fiscal measures-such as incentives, and taxes on fossil fuelswill encourage industry and societies to switch to development pathways that are less carbon-intensive.

The third is that-even if some of the historical large emitters are not making their fair share of contributions-countries that have argued for climate change justice in the past in terms of sharing the burden of reduced emissions would benefit from striving to create an economy and society that reduces anthropogenic emissions of greenhouse gases.

However, there is still a big gap between what countries committed to in Paris and what is needed to limit the increase in global warming to $2{ }^{\circ} \mathrm{C}$.

India made two ambitious commitments in Paris.

\footnotetext{
* Coordinator for this Conversations section. Ashoka Trust for Research in Ecology and the Environment, Royal Enclave Sriramapura, Jakkur Post Bangalore, India 560 064; jagdish@atree.org

Copyright (C) Krishnaswamy 2018. Released under Creative Commons AttributionNonCommercial 4.0 International licence (CC BY-NC 4.0) by the author.

Published by Indian Society for Ecological Economics (INSEE), c/o Institute of Economic Growth, University Enclave, North Campus, Delhi 110007.

ISSN: 2581-6152 (print); 2581-6101 (web).

DOI: https://doi.org/10.37773/ees.v1i1.10
} 
One was to install by 2022175 gigawatt (GW) of renewable energy (RE) capacity and operationalize it, and raise by 2030 the share of non-fossil fuels in total energy use to 40 per cent.

The other commitment was to sequester over 2.5 billion tons of carbon dioxide (CO2) through afforestation and ecological restoration.

Backed by political will at the highest levels, remarkable progress has been made on the first target. By August 2017, India had installed 58.3 GW of RE capacity. This feat has drawn international attention and praise. To achieve this target, however, the Government of India will classify hydropower projects above 25 megawatt (MW) as RE. In the Western Ghats, biodiversity has already been negatively impacted by small hydro projects. The reclassification is likely to tremendously increase the trade-off between 'green' energy and other Sustainable Development Goals (SDGs). Trade-offs with hydrologic services, livelihoods, and biodiversity is likely to impede India's attempts to achieve its carbon sequestration targets.

In agriculture, business as usual will seriously breach planetary boundaries, from water security to biodiversity and ecosystem services (Campbell 2017). All countries must make a major part of discourse the need to understand the complexities and uncertainties of governing the land-climate interface at various scales-from local to global —especially between 2030 and 2050.

The Intergovernmental Panel on Climate Change (IPCC) is preparing its Sixth Assessment Report (AR6), and IPCC scientists are working on a special report on land and climate. The report will address the issue of managing trade-offs and synergies between SDGs and ecosystem services, on the one hand, and climate change adaptation and mitigation goals, on the other.

To achieve a low-carbon-emissions pathway, governments need to pay attention to trade-offs and synergies with other development goals and muster the political will to manage these in a socially just and participative manner. 